\title{
Geographical Indications as Property: European Union Association Agreements and Investor-State Provisions
}

\author{
Anselm Kamperman Sanders*
}

\section{INTRODUCTION}

Under European Union (EU) law, geographical indications (GIs) are protected under three guises: the protected GIs (PGI), the protected designations of origin (PDOs), and the traditional specialities guaranteed (TSGs). For the $\mathrm{EU}$, the protection of its GIs in and outside of Europe is a very relevant economic issue, as the value of GI products in 2010 was estimated at $€_{54.3}$ billion, of which the sale of wines accounts for more than half. ${ }^{1}$ It is no surprise that the EU is vigorously trying to obtain protection for its GIs in major trade partner nations. However, in the context of the World Trade Organization (WTO), New World nations, most notably the North Americas, Australia and New Zealand, have consistently rejected the notion of a multilateral register for GIs that is dominated by European claims. Thus, it comes as no surprise then that in the context of the WTO negotiation mandate contained in the Agreement on Trade-Related Aspects of Intellectual Property Rights (TRIPS) ${ }^{2}$ under Article $23,{ }^{3}$ no significant progress has been made or can be expected in the near future.

* Professor of Intellectual Property Law, Director of the Advanced Masters Intellectual Property Law and Knowledge Management (IPKM LL.M/MSc), and Academic Director of the Institute for Globalization and International Regulation (IGIR), Maastricht University.

1 See Final Report of And-International on the external study: "Value of production of agricultural products and foodstuffs, wines, aromatised wines and spirits protected by a geographical indication (GI)' (October 2012), http://ec.europa.eu/agriculture/external-studies/value-gi_en.htm.

$=$ See Agreement on Trade-Related Aspects of Intellectual Property Rights, 15 April, 1994, Marrakesh Agreement Establishing the World Trade Organization, Annex 1C, 1869 U.N.T.S. 299 [hereinafter TRIPS].

3 See id. art. 23(4), which mandates that 'negotiations shall be undertaken in the Council for TRIPS concerning the establishment of a multilateral system of notification and registration of geographical indications'. 
As a result of this stalemate at the multilateral level, the strategy of the $\mathrm{EU}$ has been to place the protection of GIs at the heart of its intellectual property (IP) chapters in bilateral trade and investment agreements (BTIAs). In particular, Article $3(1)(\mathrm{e})$ of the Treaty on the Functioning of the European Union $(\mathrm{TFEU})^{4}$ provides the EU with the exclusive competence to deal with common commercial policy. ${ }^{5}$ According to Article $207(1)$ of the TFEU, ${ }^{6}$ this includes commercial aspects of IP. Not surprisingly, the number of EU BTIAs is quickly growing and the EU-South $\mathrm{Korea}^{7}$ and EUSingapore ${ }^{8}$ Free Trade Agreements (FTAs), the recent Canada-EU Trade Agreement (CETA $)^{9}$ and the EU-Vietnam Trade Agreement ${ }^{10}$ all contain annexes listing the GIs that are to be protected in the partner countries as part of the trade deal.

The nature of BTIAs, however, is that these are mixed agreements dealing with issues of tariffs and trade, but also with investment protection and, increasingly, investor-state dispute settlement (ISDS). In the context of the ongoing negotiations ISDS has become a highly controversial issue, including in the negotiation surrounding the Transatlantic Trade and Investment Partnership Agreement (TTIP). ${ }^{11}$ The controversy lies in the fact that the

4 Consolidated Version of the Treaty on the Functioning of the European Union, 10 October 2012, 2012 O.J. (C 326) 1 [hereinafter TFEU].

5 See id. Art. 3(1)(e). See Case 22/70, Comm'n v. Council, 1971 E.C.R. 263 [hereinafter ERTA]:

Each time the Community ... adopts provisions laying down common rules ..., the Member States no longer have the right, acting individually or even collectively, to undertake obligations with third countries which affect those rules.... When such common rules come into being, the Community alone is in a position to assume and carry out contractual obligations towards third countries affecting the whole sphere of application of the Community legal system. ... To the extent to which Community rules are promulgated for the attainment of the objectives of the Treaty, the Member States cannot, outside the framework of the Community institutions, assume obligations which might affect those rules or alter their scope.

6 TFEU, art. 207(1).

7 EU-South Korea Free Trade Agreement, EU-S. Kor., 16 September 2010, 54 O.J. (L 127) 1, 46-47, http://eur-lex.europa.eu/legal-content/en/ALL/?uri=OJ:L:2011:127:TOC.

8 EU-Singapore Free Trade Agreement, EU-Sing., 20 September 2013, http://ec.europa.eu/tra de/policy/countries-and-regions/countries/singapore/.

9 Comprehensive Trade and Economic Agreement, Can.-EU, Consolidated CETA Text, ch. 22, Intellectual Property, 26 September 2014, http://trade.ec.europa.eu/doclib/docs/2014/s eptember/tradoc_152806.pdf [hereinafter CETA].

10 EU-Vietnam Free Trade Agreement, EU-Viet., 5 August 2015, http://trade.ec.europa.eu/doc lib/docs/2015/august/tradoc_153674.pdf [hereinafter EU-Vietnam FTA].

11 The Transatlantic Trade and Investment Partnership (TTIP) is currently still under negotiation. Further details can be seen at In Focus: Transatlantic Trade and Investment Partnership (TTIP), Eur. Comm'n, http://ec.europa.eu/trade/policy/in-focus/ttip/ (last visited 2 June 2016). 
policy freedom of a signatory state to an agreement containing ISDS may become limited on account of investor expectations that have to be honoured. The controversy is remarkable to the extent that ISDS has been a prominent feature in international trade and investment frameworks since the mid-1970s. In fact, the proliferation of ISDS in bilateral agreements is so widespread and affects so many trading nations globally ${ }^{12}$ that it is almost surprising that relatively few cases have been brought so far claiming violations under these provisions. Also regional trade agreements like the North American FTA $(\mathrm{NAFTA})^{13}$ and the Trans-Pacific Partnership Agreement (TPP) ${ }^{14}$ contain ISDS clauses.

However, the concept of ISDS is relatively new in the field of IP. This is due to the fact that IP only became a global trade issue relatively recently through the integration of IP standards and IP enforcement in the WTO framework. That said, IP is also peculiar in the sense that the valuation of IP as an object of property that can be viewed as an investment is also a relatively new concept. Even now, various approaches to valuation according to income-based, market-based and review of cost-based approaches, coupled with diverging reporting standards, yield different results. ${ }^{15}$ Still, the number of ISDS complaints is rising and the first cases involving core issues of IP expropriation are currently pending.

Of all IP rights, the EU regime on the protection of GIs invites a substantial involvement of public authority in defining GI specifications, as well as the quality maintenance thereof. This means that any change in the specification may give rise to an investor-state dispute. This chapter charts the likelihood that GIs may become a bone of contention under constitutional expropriation protection laws, WTO disputes and ISDS, and concludes that given the nature of GI protection's inclusion of specifications, there is a higher state involvement, and accordingly, a higher likelihood that measures negatively affecting a GI proprietor's rights can be attributed to a state.

12 A short internet search also reveals that ISDS is not exclusive to trade deals involving Western nations. Asian countries are equally parties to such agreements, also when it concerns their regional trade and investment partners.

13 North American Free Trade Agreement, US-Can.-Mex., 17 December 1992, 32 I.L.M. 289 (1993) [hereinafter NAFTA].

14 Trans-Pacific Partnership, ch. 18, Intellectual Property, 5 November 2015, https://medium .com/the-trans-pacific-partnership/intellectual-property-3479efdc7adf\#.ux18hliwo [hereinafter TPP, Intellectual Property Chapter].

15 See Final Report from the Expert Group on Intellectual Property Valuation (29 November 2013), https://ec.europa.eu/research/innovation-union/pdf/Expert_Group_Report_on_Intelle ctual_Property_Valuation_IP_web_2.pdf. 


\section{GEOGRAPHICAL INDICATIONS AND SPECIFICATIONS}

IN THE EUROPEAN UNION

The EU PGI, PDO and TSG schemes operate on the basis of registration in the Database of Origin and Registration (DOOR). ${ }^{16}$ There are also product-specific regimes and databases, such as the E-BACCHUS ${ }^{17}$ for wines and E-SPIRIT DRINKS $^{18}$ for spirits. EU law also protects GIs for aromatized wine products. ${ }^{19}$ Generally, EU law applies to products originating from EU Member States and third countries that comply with EU rules. Alongside the existing public registries, there are several certification schemes for agricultural products and foodstuffs in the EU. These range from compliance obligations with compulsory production standards to additional voluntary requirements relating to environmental protection, animal welfare, organoleptic qualities, etc. Also, all kinds of 'fair trade' or 'slave free' epithets fall within these voluntary regimes. All these regimes should, however, be in compliance with the 'EU best practice guidelines for voluntary certification schemes for agricultural products and foodstuffs', ${ }^{20}$ in order to be in compliance with EU law.

In 2005, the United States (the US) and Australia successfully challenged the legitimacy of EC Regulation 2081/92 $2^{21}$ on GIs for agricultural products and foodstuffs, which was the regulation in force at the time, before the WTO. The regulation contained a number of contentious provisions, namely on (1) the equivalence and reciprocity conditions in respect of GI protection; (2) procedures requiring non-EU nationals, or persons resident or established in non$\mathrm{EU}$ countries, to file an application or objection in the European Communities through their own government, but not directly with EU Member States; and (3) a requirement on third-country governments to provide a declaration that structures were in place on their territory enabling the inspection of compliance with the specifications of the GI registration. On all three points, the WTO Panel ${ }^{22}$ found violations of Article 3(1) of

16 See DOOR, Eur. Comm'n, http://ec.europa.eu/agriculture/quality/door/list.html (last visited 5 June 2016).

17 See E-Bacchus, Eur. Comm'n, http://ec.europa.eu/agriculture/markets/wine/e-bacchus/.

18 See E-Spirit-Drinks, Eur. Comm'n, http://ec.europa.eu/agriculture/spirits/.

19 Council regulation 1601/91 of 10 June 1991, laying down general rules on the definition, description and presentation of aromatized wines, aromatized wine-based drinks and aromatized wine-product cocktails, 1991 O.J. (L 149) 1.

2o Commission Communication - EU best practice guidelines for voluntary certification schemes for agricultural products and foodstuffs, 2010 O.J. (C 341) 4, 5 .

${ }_{21}$ Council Regulation 2081/92 of 14 July 1992, on the protection of GIs and designations of origin for agricultural products and foodstuffs, 1992 O.J. (L 208) 1-8.

22 Complaint by the United States, EC - Trademarks and Geographical Indications for Agricultural Products and Foodstuffs, WTO Doc. WT/DS174/R (adopted 20 April 2005); 
TRIPS $^{23}$ and Article III $(4)$ of the General Agreement on Tariffs and Trade 1994 (GATT) ${ }^{24}$ and that the GATT violations were not justified by Article XX(d) of GATT. ${ }^{25}$ In the Australian Report, the WTO Panel further found that these inspection structures did not constitute a 'technical regulation' within the meaning of the Agreement on Technical Barriers to Trade (TBT) ${ }^{26}$ As a result, the EU changed its regime in March 2006 to ensure compliance with the WTO regime, currently primarily through the Foodstuffs Regulation, ${ }^{27}$ and corresponding provisions in the other Regulations. ${ }^{28}$ The scope or protection extends to consumer deception; ${ }^{29}$ commercial use in comparable products; $;^{30}$ commercial use exploiting reputation; ${ }^{31}$ and misuse, imitation or evocation ${ }^{32}$ in relation to the registered GI. The enforcement of a GI is, however, a private law issue.

More interesting, for the purpose of this chapter, however, is the product specification - its establishment, inspection and enforcement - as this requires the involvement of public authority. The definition of the product according

Complaint by Australia, EC - Protections of Trademarks and Geographical Indications for Agricultural Products and Foodstuffs, WTO Doc. WT/DS29o/R (adopted 20 April 2005); see also Lothar Ehring, National Treatment Under the GATT 1994, in The Principle of National Treatment in International Economic Law - Trade, Investment and Intellectual Property 34-54 (Anselm Kamperman Sanders ed., 2014) [hereinafter The Principle of National Treatment in International Economic Law]; Anselm Kamperman Sanders, National Treatment Under the TRIPS Agreement, in THE PrINCIPLE OF National Treatment in International Economic LaW, supra, at 286-99.

23 See TRIPS, art. 3(1) (obligating National Treatment (NT) in respect of WTO Member States).

24 See General Agreement on Tariffs and Trade, 15 April 1994, Marrakesh Agreement Establishing the World Trade Organization, Annex 1A, Legal Instruments - Results of the Uruguay Round, art. III(4), 1867 U.N.T.S. 187 (1994) [hereinafter GATT 1994].

25 GATT 1994, art. XX(d) (providing that an exception can be made to measures falling foul of the mandated standards if they are 'necessary to secure compliance with laws or regulations').

26 See Agreement on Technical Barriers to Trade, GATT Secretariat. Uruguay Round of Multilateral Trade Negotiations: Legal Instruments Embodying the Results of the Uruguay Round of Multilateral Trade Negotiations done at Marrakesh on 15 April 1994 (2003), GATT Doc. MTN/FA II-A1A-6 (15 December 1993) [hereinafter TBT], www.wto.org/english/docs_e/ legal_e/17-tbt.pdf.

27 Regulation 1151/2012 concerning certain foodstuffs and certain non-food agricultural products (the 'Foodstuffs Regulation'), 2012 O.J. (L 343), 1-29.

28 Regulation 1308/2013 concerning wines and sparkling wines, 2013 O.J. (L 347) 671-854; Regulation 110/2008 on the definition, description, presentation, labelling and the protection of geographical indications of spirit drinks, 2008 O.J. (L 39) 16-54; Council Regulation 1601/91 of 10 June 1991, laying down general rules on the definition, description and presentation of aromatized wines, aromatized wine-based drinks and aromatized wine-product cocktails, 1991 O.J. (L 149) 1-9.

292012 O.J. (L 343), art. 13 (c)-(d). $\quad 30 \quad 2012$ O.J. (L 343), art. 13(a). ${ }^{31} \quad$ Id.

32 Id. art. $13(\mathrm{~b})$. 
to precise specifications and its analysis by national authorities is a process integral to the registration of the GI at the EU level.

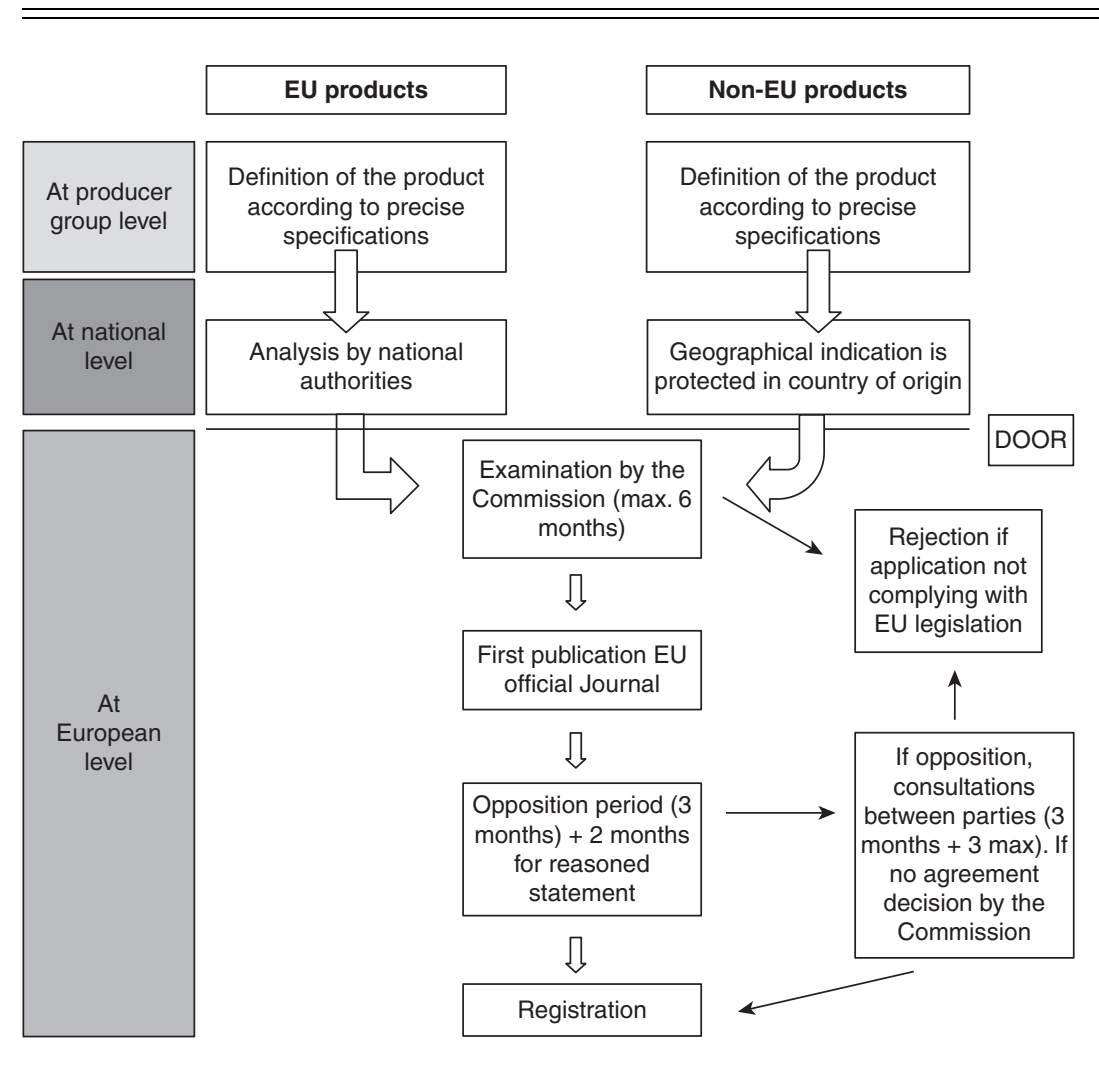

Figure 7.1 Source: European Commission, http://ec.europa.eu/agriculture/quality/ schemes/index_en.htm

The definition of the product comprises the following elements: the product name, applicant details, product class, the name of the product, the description of the product, a definition of the geographical area, proof of the product's origin, a description of the method of production, the linkage between the product and the area, the nomination of an inspection body and labelling information. ${ }^{33}$ For PDOs, all production steps must take place within the geographical area, whereas for PGIs at least one production step must take place within the geographical area. It is also at this point where

33 See Guide to Applicants, Eur. Comm'n, http://ec.europa.eu/agriculture/quality/schemes/gu ides/guide-for-applicants_en.pdf (last visited 5 June 2016). 
specific rules concerning slicing, grating, packaging and the like of the product to which the registered name refers may be stated and justified. Given the fact that these types of conditions on repackaging or slicing result in geographical restrictions having strong protectionist and anticompetitive effects, they are among the most controversial specifications.

In 1997, the Consorzio del Prosciutto di Parma, ${ }^{34}$ the Italian trade association of 200 traditional producers of Parma Ham, sought injunctions against Asda Stores in the United Kingdom to restrain them from selling pre-sliced packets of prosciutto as 'Parma Ham', a protected PDO. The ham was sliced by a supplier of Asda outside the production region, and pre-packaged without supervision by the inspection body responsible for enforcing $\mathrm{EU}$ production regulations. The slicing of the ham itself cannot be problematic as such, ${ }^{35}$ but the question is whether slicing the ham away from the consumer's eyes and offering them as a pre-packaged product not bearing the Consorzio's mark would be infringing upon the PDO. The Consorzio's argument was that the consumer could not verify the origin, and the quality of the ham could not be guaranteed. The Court of Justice of the European Union $\left(\mathrm{CJEU}^{36}\right)$ held ${ }^{37}$ that protection conferred by a PDO did not normally extend to operations such as grating, slicing and packaging the product. The CJEU, however, stated that those operations were prohibited to third parties outside the region of production only if they were expressly laid down in the specification, and if this condition was brought to the attention of economic operators by adequate publicity in Community legislation. The latter was not yet the case under the old regime. ${ }^{38}$ Under Article $8.2^{39}$ of Regulation 1151/2012, the product specification is now to be included in the single document that is contained in the DOOR register, and the Consorzio can now enforce its slicing and packaging rules.

The specification also contains the names of the inspection bodies responsible for enforcing EU production regulations. ${ }^{4^{\circ}}$ In each Member State,

See Prosciutto di Parma, www.prosciuttodiparma.com/ (last visited 5 June 2016). One can follow the hilarious videos of the 'Prosciutto di Parma DOP slicing instruction' videos on YouTube. ProsciuttodiParmaDOP, English Tutorial: Preparing and Slicing Parma Ham, YouTube (16 October 2012), www.youtube.com/watch?v=_qfVIzmqlGE.

Formerly European Court of Justice (ECJ).

Case C-108/or, Consorzio del Prosciutto di Parma en Salumificio S. Rita SpA v. Asda Stores Ltd and Hygrade Foods Ltd., 2003 E.C.R. I-5163.

Regulation 2081/92 on the protection of geographical indications and designations of origin for agricultural products and foodstuffs, 1992 O.J. (L 208) $1-8$. 2012 O.J. (L 343), art. 8(2).

For a list of inspection bodies, see EuR. Comm'N, http://ec.europa.eu/agriculture/quality/sc hemes/compliance-authorities_en.pdf (last visited 5 June 2016). 
public authorities or government agencies are entrusted with this task. When it comes to defining or redefining the specification, however, quite a lot of state involvement can be observed. A case on point is the enlargement in 2009, actively supported by the Italian government, of the area of production for 'Italian Prosecco'. ${ }^{41}$ The production of this sparkling wine has been traditionally confined to the Veneto Region around Venice, but it was suddenly 'strategically' expanded to include the town of Prosecco, which is located in the Friuli-Venezia Giulia Region near Trieste and the Slovenian border. This is the place where the Prosecco grape variety is believed to have originated from. Yet, upon accession to the EU in 2013, Croatia found that its sweet Prošek dessert wine, which is different from Italian Prosecco in all aspects of methods of production and grapes used, could no longer coexist in the EU with Italian Prosecco. ${ }^{42}$

In short, GIs are peculiar in the sense that they constitute a type of IP right where a lot of state involvement can be observed, especially in the drafting, maintenance and alteration of the GI's specification. This may lead to the consortium of GI producers, or the (semi-)state authority itself to alter a GI specification after the GI has been registered. As a consequence, this may give rise to investor-state disputes by private parties that may consider themselves affected by these changes or the recognition of GIs in general (in that they may no longer be able to market their products under the same or similar names), since many of these measures leading to the definition of the GI's specification can be directly or indirectly attributed to the state.

\section{GEOGRAPHICAL INDICATIONS AS PROPERTY}

Like other IP rights, GIs are protected as proprietary interests. This becomes apparent from the WTO Panel report in EC - Trademarks and Geographical Indications,${ }^{43}$ but even more so in the context of the European Convention on Human Rights (ECHR).

In the case of Anheuser-Busch v. Portugal, the European Court of Human Rights (ECtHR) held that the protection provided for by Article 1 of the

$4^{11}$ See Prosecco Wine, Wine-Searcher, www.wine-searcher.com/regions-prosecco (last visited 7 November 2013), for a brief summary; Filippo Mattia Ginanni, The 2009 Prosecco DOC Reform, Wine \& SPIRIT EDUC. TR., www.wsetglobal.com/documents/julian_brind_scholar ship_2015_prosecco_reform_filippo_ginanni.pdf.

$4^{2}$ See Anselm Kamperman Sanders, Geographical Indications of Origin: When GIs Become Commodities, All Gloves Come Off, 46 IIC-Int'l Rev. Intell. Prop. \& Competition L. (IIC) 755-59 (2015).

431992 O.J. (L 208) 1-8. 
Protocol No.1 to the ECHR, ${ }^{44}$ which guarantees the right to property, ${ }^{45}$ is applicable to IP as such. ${ }^{46}$ This means that the owner of an intellectual 'possession' is protected in respect of (1) the peaceful enjoyment of property; (2) deprivation of possessions and the conditions thereto; and (3) the control of the use of property by the state in accordance with general interest. Inherent in the convention is the recognition that a fair balance needs to be struck between the demands of the general interests of society and the requirements of the protection of the individual's fundamental rights. ${ }^{47}$

Since 2000 the EU Charter on the Protection of Fundamental Human Rights ${ }^{4}$ recognized similar principles that EU citizens can rely on. In Scarlet Extended v. Sabam, ${ }^{49}$ the CJEU held:

The protection of the right to intellectual property is indeed enshrined in Article 17(2) of the Charter of Fundamental Rights of the European Union

See Monica Carss-Frisk, A Guide to the Implementation of Article 1 of the Protocol No. 1 to the European Convention on Human Rights, in Human Rights Handbook (Eur. Council, Human Rights Handbooks No. 4, 2001), www.echr.coe.int/LibraryDocs/DG2/HRHAND/D G2-EN-HRHAND-04(2003).pdf.

45 Convention for the Protection of Human Rights and Fundamental Freedoms Protocol 1 art. 1, 4 November 1950, 213 U.N.T.S. 222 (European Convention on Human Rights) [hereinafter ECHR]:

Every natural or legal person is entitled to the peaceful enjoyment of his possessions. No one shall be deprived of his possessions except in the public interest and subject to the conditions provided for by law and by the general principles of international law.

The preceding provisions shall not, however, in any way impair the right of a state to enforce such laws at it deems necessary to control the use of property in accordance with the general interest or to secure the payment of taxes or other contributions or penalties.

$4^{6}$ Anheuser-Busch Inc. v. Portugal, App. No. 73049/o1, 44 Eur. H.R. Rep. 42, para. 72 (2007) (stating that 'Article 1 of Protocol No. 1 is applicable to intellectual property as such', but in the case at hand decided that legitimate regulatory interests may justify interference with the right of property in line with the court's general approach to interference with the right to property). See also Anselm Kamperman Sanders, Professional Case Comment, Case No. 73049/o1 of the Grand Chamber of the ECHR, Anheuser-Bush Inc.v. Portugal, 4 Eur. Human Rights Cases (EHRC) 433-37 (2007).

47 See James v. the United Kingdom, 8 Eur. H.R. Rep. A98, para. 46 (1986).

$4^{8}$ Charter of Fundamental Rights of the European Union art. 17, 18 December 2000, 2000 O.J. $\left(\mathrm{C}_{364}\right)_{1}$, on the right to property provides:

1. Everyone has the right to own, use, dispose of and bequeath his or her lawfully acquired possessions. No one may be deprived of his or her possessions, except in the public interest and in the cases and under the conditions provided for by law, subject to fair compensation being paid in good time for their loss. The use of property may be regulated by law in so far as is necessary for the general interest.

2. Intellectual property shall be protected.

49 Case C-7o/10 Scarlet Extended v. Société Belge des auteurs, compositeurs et éditeurs SCRL (SABAM), 2011 E.C.R. I-11959. 
('the Charter'). There is, however, nothing whatsoever in the wording of that provision or in the Court's case-law to suggest that that right is inviolable and must for that reason be absolutely protected ... The protection of the fundamental right to property, which includes the rights linked to intellectual property, must be balanced against the protection of other fundamental rights.

Opinions on how this balance should be struck, however, naturally differ, depending on one's perspective. In a European case, British American Tobacco, ${ }^{50}$ involving challenges to restrictions on advertising, branding and trademark communication in relation to tobacco products, the CJEU held that restrictions on trademark use requiring labels to display health warnings by taking up 30 per cent of the front and 40 per cent of the back of a cigarette package ${ }^{51}$ amount to a legitimate restriction that still allows for a normal use of the trademark. The tobacco companies had argued that there is a de facto expropriation of their property in the trademark. A similar argument was made in the well-publicized constitutional challenge case to the Australian Tobacco Plain Packaging Act 2011. ${ }^{22}$ The High Court of Australia in BAT v. Commonwealth of Australia ${ }^{53}$ held that there was no acquisition of property that would have required so-called 'just terms' protection under the Australian constitution. Yet it is the Australian Tobacco Plain Packaging Act 2011 that has also produced two WTO challenges to tobacco plain packaging, by Ukraine ${ }^{54}$ and by a number of other states. ${ }^{55}$ Although Ukraine suspended its proceedings on 28 May 2015, the litigation by Honduras, Cuba, Indonesia and the

50 Case C-491/o1, The Queen v. Secretary of State for Health, ex parte British American Tobacco (Investments) Ltd and Imperial Tobacco Ltd., 2002 E.C.R. I-11453.

51 Current requirements are even more stringent under Directive 2014/40/EU, of the European Parliament and of the Council of 3 April 2014, on the approximation of the laws, regulations and administrative provisions of the Member States concerning the manufacture, presentation and sale of tobacco and related products and repealing Directive 2001/37/EC, 2014 O.J. (L 127) 1, with Arts. 8-10 amounting to a ' $75 \%$ rule' in terms of the package having to display health warnings.

52 See Tobacco Plain Packaging Act 2011 (Austl.).

53 British American Tobacco Australasia Limited and Ors v. Commonwealth of Australia, 2012 250 CLR 1.

54 Complaint by Ukraine, Australia - Certain Measures Concerning Trademarks, and Other Plain Packaging Requirements Applicable to Tobacco Products and Packaging, WTO Doc. WT/DS $343 / 1$ (13 March 2012).

55 Complaint by Honduras, Australia - Certain Measures Concerning Trademarks, Geographical Indications and Other Plain Packaging Requirements Applicable to Tobacco Products and Packaging, WTO Doc. WT/DS435/1 (4 April 2012 [hereinafter Australia - Certain Measures Concerning Trademarks); Complaint by Dominican Republic, Australia - Certain Measures Concerning Trademarks, WTO Doc. WT/DS441/1 (18 July 2012); Complaint by Cuba, Australia - Certain Measures Concerning Trademarks, WTO Doc. WT/DS $458 / 1$ (3 May 
Dominican Republic remains unaffected. Plain packaging also sparked investor-state disputes. ${ }^{56}$ These cases raise questions on the remaining policy freedom that nation states have in regulating the use or exercise of IP in light of societal interests, such as public health, in the context of multilateral and bilateral trade agreements, and investment protection agreements.

\section{INVESTOR-STATE DISPUTE SETTLEMENT AND WTO LAW}

Bilateral free trade and investment agreements may provide additional protection to investors in relation to their investments that are then considered to be 'possessions' in the state where such investments have been made. The question is then to what extent protection granted by means of bilateral agreements changes the legal relations between WTO Members. Although the annexes to EU BTIAs list GIs that are to be protected under the agreement, ${ }^{57}$ it remains to be examined what their effect under the WTO Dispute Settlement Understanding (DSU) is.

The WTO Appellate Body, in Mexico - Taxes on Soft Drinks, ${ }^{5}$ rejected the notion that parties can modify WTO obligations by means of an FTA, whereas the WTO Panel in Peru - Additional Duty ${ }^{59}$ was not so categorically opposed. In the latter case, there are numerous references to Peru's freedom to maintain a price range system (PRS) under an FTA with complainant Guatemala. The WTO Panel, however, observed that the FTA in question was not yet in force, and that its provisions should therefore have limited legal effects on the dispute at hand. Peru's arguments in respect of the FTA were that, even assuming that Peru's PRS was WTO-inconsistent, Peru and Guatemala had modified between themselves the relevant WTO provisions to the extent that the FTA allowed Peru to maintain the PRS. Upon appeal, the Appellate Body stated:

$[\mathrm{W}] \mathrm{e}$ are of the view that the consideration of provisions of an FTA for the purpose of determining whether a Member has complied with its WTO obligations involves legal characterizations that fall within the scope of appellate review under Article 17.6 of the DSU. ${ }^{60}$

2013); and Complaint by Indonesia, Australia - Certain Measures Concerning Trademarks, WTO Doc. WT/DS467/1 (20 September 2013).

${ }_{56} \quad$ See infra Section $5 . \quad 57$ See supra Section 1.

$5^{8}$ Appellate Body Report, Mexico - Tax Measures on Soft Drinks and Other Beverages, WTO Doc. WT/DS308/AB/R, (adopted 6 March 2006).

59 Panel Report, Peru - Additional Duty on Imports of Certain Agricultural Products, WTO Doc. WT/DS457/R (adopted 27 November 2014) [hereinafter Additional Duty Panel Report].

6o Appellate Body Report, Peru - Additional Duty on Imports of Certain Agricultural Products, 5.86 WTO Doc. WT/DS457/AB/R (adopted 20 July 2015). 
However, it also considered that WTO Members cannot modify WTO provisions such that these become WTO-inconsistent, even if these changes 'merely' operate bilaterally inter partes and not amongst all WTO Members. In particular, the Appellate Body held:

We note, however, that Peru has not yet ratified the FTA. In this respect, it is not clear whether Peru can be considered as a 'party' to the FTA. Moreover, we express reservations as to whether the provisions of the FTA (in particular paragraph 9 of Annex 2.3), which could arguably be construed as to allow Peru to maintain the PRS in its bilateral relations with Guatemala, can be used under Article 31(3) of the Vienna Convention in establishing the common intention of WTO Members underlying the provisions of Article 4.2 of the Agreement on Agriculture and Article II:1(b) of the GATT 1994. In our view, such an approach would suggest that WTO provisions can be interpreted differently, depending on the Members to which they apply and on their rights and obligations under an FTA to which they are parties. ${ }^{61}$

In the case at hand, this means that Peru under the FTA is only allowed to maintain a WTO-consistent PRS, which should meet the requirements of Article XXIV ${ }^{62}$ of the GATT 1994, which permits certain specific deviations from WTO rules. All such departures require that the level of duties and other regulations of commerce applicable in each of the FTA members to the trade of non-FTA members shall not be higher or more restrictive than those applicable prior to the formation of the FTA. ${ }^{63}$

In Turkey - Textiles, ${ }^{6}{ }_{4}$ the Appellate Body held that the justification for measures that are inconsistent with certain GATT 1994 provisions requires the party claiming the benefit of the defence provided for by Article XXIV GATT 1994 lies in closer integration between the economies of the countries party to such an agreement. It is clear that Peru's PRS measure cannot be interpreted as a measure fostering closer integration; rather, it results in the opposite. The GI 'claw-back' annexes to EU BTIAs can arguably be held to contain obligations that approximate the economies of the parties to the agreement, providing the holder of such a GI legal certainty not only as to the protection and enforcement of the GI but also as to the protection of an 'investment' in terms of production and marketing of a GI product.

61 Additional Duty Panel Report, supra note 60, at 5.106.

62 GATT 1994 art. XXIV(5) (providing that parties can form custom unions or free trade areas, subject to certain conditions being met).

63 GATT 1994 art. XXIV(5)(a).

64 Appellate Body Report, Turkey - Restrictions on Imports of Textile and Clothing Products, WTO Doc. WT/ DS 34/AB/R (adopted 19 November 1999). 
The WTO Dispute Settlement Body has meanwhile established dispute settlement panels in relation to Australia's tobacco plain packaging measure. GIs are part of the property package on which the claim is based. The five complainants are arguing that the measure is inconsistent with Australia's WTO obligations under TRIPS,,${ }_{5}$ TBT $^{66}$ and the GATT $1994 .{ }^{67}$ In respect of trademarks and GIs, the claim is that restrictions on their use amount to an expropriation of property. There is only one caveat that will be of relevance to a decision in these cases ${ }^{68}$ in the context of TRIPS, and that is that in EC Geographical Indications, the panel held:

[T] he TRIPS Agreement does not generally provide for the grant of positive rights to exploit or use certain subject matter, but rather provides for the grant of negative rights to prevent certain acts. This fundamental feature of intellectual property protection inherently grants Members freedom to pursue legitimate public policy objectives since many measures to attain those public policy objectives lie outside the scope of intellectual property rights and do not require an exception under the TRIPS Agreement. ${ }^{69}$

\section{INVESTOR-STATE DISPUTE SETTLEMENT AND GEOGRAPHICAL} INDICATIONS

The ISDS case of Philip Morris Asia v. Australia ${ }^{70}$ shows that investor-state disputes can be brought in support of, or as an alternative to, constitutional and WTO challenges. In this case, Philip Morris Asia challenged the tobacco plain packaging legislation under the 1993 Agreement between the Government of Australia and the Government of Hong Kong for the Promotion and Protection of Investments. The arbitration was conducted under the United Nations Commission on International Trade Law (UNCITRAL) Arbitration Rules 2010. ${ }^{71}$ In a decision of 18 December 2015,

65 TRIPS, supra note 2. $66 \quad$ TBT, supra note $26 . \quad{ }^{6} 7 \quad$ GATT 1994 art. III(4).

68 See supra notes 54 \& 55. The Chair of the panel informed the Dispute Settlement Body on 10 October 2014 that the panel expects to issue its final report to the parties in the second half of 2016.

69 See Panel Report, EC-Trademarks and Geographical Indications, 7.210, WTO Doc. WT/DS/ ${ }_{174} \mathrm{R}$ (adopted 15 March 2005).

70 Philip Morris Asia Limited (Hong Kong) v. The Commonwealth of Australia, Case No. 2012-12 (Perm. Ct. Arb. 22 June 2011), www.pcacases.com/web/view/5.

$7^{1}$ UNCITRAL Arbitration Rules, U.N. Comm'N InT'L Trade L., www.uncitral.org/uncitral/ en/uncitral_texts/arbitration/2010Arbitration_rules.html (last visited 6 June 2016). 
the Tribunal hearing the case ruled that it had no jurisdiction to hear Philip Morris Asia's claim.

However, it is important to realize that the proliferation of ISDS clauses in bilateral trade agreements is increasing. Investor-state dispute settlement revolves around the question of whether expropriation, directly or indirectly, has been conducted according to the principles of Fair and Equitable Treatment (FET). FET is determined through applying principles of (1) reasonableness, (2) consistency, (3) non-discrimination, (4) transparency and (5) due process. In this context, the legitimate expectations of an investor are taken into consideration in order to assess whether the state has expropriated in bad faith, through coercion, by means of threats or harassment. Due to the fact that there is no true harmonized multilateral dispute settlement system in relation to investment disputes, the interpretation and application of these principles are not uniform. Due to the confidential nature of arbitration, not all arbitration reports are public. The most concrete expressions of what legitimate investor expectations are can be found in statements made in published cases that seem to indicate that a balance must be struck.

For example, in International Thunderbird v. Mexico, ${ }^{72}$ a NAFTA dispute conducted under UNCITRAL Arbitration Rules, the panel held:

[A] situation where a Contracting Party's conduct creates reasonable and justifiable expectations on the part of an investor (or investment) to act in reliance on said conduct, such that a failure by the NAFTA Party to honour those expectations could cause the investor (or investment) to suffer damages. ${ }^{73}$

Conversely, in Saluka v. Czech Republic, ${ }^{74}$ an investor-state dispute also conducted under UNCITRAL Arbitration Rules, the panel held:

No investor may reasonably expect that the circumstances prevailing at the time the investment is made remain totally unchanged. In order to determine whether frustration of the foreign investor's expectations was justified and reasonable, the host State's legitimate right subsequently to regulate domestic matters in the public interest must be taken into consideration as well. ${ }^{75}$

72 International Thunderbird Gaming Corporation v. The United Mexican States, NAFTA, Arbitral Award (26 January 2006), www.iisd.org/pdf/2006/itn_award.pdf.

73 Id. at 49 , para. 147.

74 Saluka Investments BV (The Netherlands) v. Czech Republic, Partial Award, (Perm. Ct. Arb. 17 March 2006), http://archive.pca-cpa.org/SAL-CZ\%20Partial\%2oAward\%20170306ba57.pdf ?fil_id=105.

75 Id. at 66 , para. 305 . 
There are few ISDS cases involving IP. ${ }^{76}$ These are cases that have been argued under the rules of the International Centre for Settlement of Investment Disputes (ICSID), which is an independent branch of the World Bank.

First, there was a failed attempt at arguing a trademark infringement case under investor-state dispute settlement in AHS v. Niger. ${ }^{77}$ In this case, although a concession to service Niger's national airport had been terminated, there was continued use of seized equipment and uniforms bearing the trademarks of the complainant. The panel held that it had no jurisdiction, as IP enforcement is a civil matter that cannot be raised in the context of the ISDS expropriation complaint.

Second, there is the ongoing case of Philip Morris v. Uruguay ${ }^{8}$ that is argued under the Uruguay-Switzerland FTA, ${ }^{79}$ and where the legitimacy of plain packaging tobacco products is challenged. In this case jurisdiction has been established and proceedings on the merits are to follow.

Third, there is a NAFTA ${ }^{80}$ case argued under UNCITRAL Arbitration Rules. In Eli Lilly v. Canada, ${ }^{81}$ pharmaceutical company Eli Lilly sought damages for $\$ 100$ million CAD and challenged changes to the patentability requirements in respect of utility or industrial applicability, leading the Canadian patent office to invalidate two of Eli Lilly's patents for the Strattera attention-deficit disorder pill and the Zyprexa antipsychotic treatment. Eli Lilly argued that the interpretation of the term 'useful' in the Canadian Patent Act by the Canadian courts led to an unjustified expropriation and a violation of Canada's obligations under NAFTA on the basis that it is arbitrary and discriminatory. Canada conversely argued that Eli Lilly's claims were beyond the jurisdiction of the Tribunal. Ultimately, in March 2017, the Tribunal dismissed Eli Lilly's claims and confirmed that Canada was in compliance with its NAFTA obligations. ${ }^{82}$

$7^{6}$ For a comprehensive overview, see H. Grosse Ruse-Khan, Litigating Intellectual Property Rights in Investor-State Arbitration: From Plain Packaging to Patent Revocation (Univ. Cambridge, Legal Studies Research Paper Series No. 52, 2014).

77 AHS Niger and Menzies Middle East and Africa S.A. v. Republic of Niger, ICSID Case No. ARB/ 11/11 Award (15 July 2013), www.italaw.com/sites/default/files/case-documents/italaw3034.pdf.

$7^{8}$ Philip Morris Brands Sàrl v. Oriental Republic of Uruguay, ICSID Case No. ARB/10/7, www .italaw.com/cases/46o.

79 Agreement Between the Swiss Confederation and the Oriental Republic of Uruguay on the Recipocal Promotion and Protection of Investments, 7 October 1988, 1976 U.N.T.S. 389.

8o NAFTA, supra note 13 .

81 Eli Lilly and Co. v. The Government of Canada, ICSID Case No. UNCT/14/2 NAFTA (7 November 2012).

82 Eli Lilly and Co. v. The Government of Canada, ICSID Case No. UNCT/14/2 Final Award (16 March 2017). 
Cases involving IP can be and are clearly brought if measures negatively impacting upon the 'investment' can be attributed to a state that has submitted to ISDS. Issues such as IP enforcement or thresholds for patentability as such appear to be outside of the remit of ISDS, as these are civil or administrative matters where access to judicial review is usually provided. However, complaints over (arbitrary or discriminatory) denial of justice may not be. In the cases described above, one can argue that the general measures taken are neither of an arbitrary nor discriminatory nature. GI specifications, on the other hand, are discriminatory by nature since they are always specifically targeted, and this characteristic exceeds the already exclusionary nature of an IP right. This is because, as we have seen, the definition of the product comprises not only the product name and related labelling but also the description of the product, a definition of the geographical area, proof of the product's origin, a description of the method of production, the linkage between the product and the area, the nomination of an inspection body empowered to police the specification.

This means that there are a number of actions that may have an immediate impact, not only on the existence and exercise of a GI, but also on its value and costs. The example of the Italian Prosecco DOC reform ${ }^{8}$ comes to mind, as an enlargement of the geographical area, but also a possible reduction thereof has immediate effects for producers within and outside of the area. Production methods may also be subject to changes. Changes to production requirements resulting from a raise in food safety standards may be legitimized within the context of the WTO Agreement on the Application of Sanitary and Phytosanitary Measures (SPS). ${ }^{84}$ Many of the GI production requirements are, however, steeped in a tradition and culture that solicit the demand for a particular product. If one, for example, orders Limburg Grotto Cheese, ${ }^{85}$ one expects the cheese to have been ripened through completely natural processes by exposure of the cheese to the atmosphere of a limestone cave that contains the Brevibacterium Linens that produces a cheese with a pungent odour. The cheeses ripen on oak wooden boards and need to be turned regularly. This is a delicate operation as the fungi growing on the cheeses are poisonous. The result of food safety standards (no oak, stainless steel racks, etc.) has been that the traditional production for the traditional connoisseur

83 See supra note 41 .

${ }^{8}$ See Agreement on the Application of Sanitary and Phytosanitary Measures, 15 April 1994, Marrakesh Agreement Establishing the World Trade Organization, Annex 1, 1867 U.N.T.S. 493.

85 The 'Duchy of Limburg' was a state in the Holy Roman Empire (1065-1794) and a part of the German Confederation (1839-1867). Since 1839 'Limburg' is a province in Belgium, and a province in the Netherlands. Furthermore, it is the name of a town in Belgium, and in Germany it is used in respect of various cities, towns, a castle, abbey and airfield. 
consumer has now moved literally and figuratively underground. As a result, only the more industrial producers remain around to sell a product that is compliant with legal standards. They are selling a product that may be safer (although this is often disputed) but is certainly far less traditional than the consumer is led to believe. Phasing-out rules concerning slicing, grating, packaging, etc. stem from a desire to free the market from anticompetitive restrictions, but arguably these could also be measures that have a negative impact on the investments made by producers benefitting from GI specifications containing such rules. These forms of proprietary protection of GIs via individual regulations are also open to non-European entities, as we have seen above. So, a US association that holds an EU GI, such as the Idaho Potato Commission, ${ }^{86}$ could then also sue before the special ISDS courts envisaged under the TTIP ${ }^{87}$ for a weakening or strengthening of protection standards in Europe. In most cases, after all, the measure can be attributed to the state, and despite attempts by EU Member States to deny private parties the right to invoke international treaties, the CJEU has affirmed the direct effect of international treaties that bind the EU. ${ }^{88}$

\section{CONCLUSION}

More than any other IP, a GI displays a very high level of state involvement in relation to specifications that do not directly concern the exercise of the IP right in terms of protection against consumer confusion and the like, but that very much influences the value of the GI for its owner. Definitions of territory, methods of production, sanitary and phytosanitary standards, and other more nefarious rules concerning slicing, grating, packaging, etc. can be changed at the behest of members of the consortium, but also of (semi-)state authorities or

See Idaho Potato Comm'n, https://idahopotato.com (last visited 6 June 2016).

EU-Vietnam FTA, supra note 10.

88 Case C-104/81, Hauptzollamt Mainz v. C.A. Kupferberg, 1982 E.C.R. 3641. See also Case C-265/03, Igor Simutenkov v. Ministerio de Educación y Cultura and Real Federación Española de Fútbol (EU-Russia Partnership Agreement), 2005 E.C.R. I-2579 (precluding imposing limits in fielding individual sportsmen from non-EEA members). But see Case C-24o/og, Lesoochranárske zoskupenie VLK v. Ministerstvo životného prostredia Slovenskej republiky (Aarhus Convention), 2011 E.C.R. I-1255 (holding that in the absence of EU rules governing the matter, it is for the domestic legal system of each Member State to lay down the detailed procedural rules governing actions for safeguarding rights which individuals derive from EU law); Joined Cases C-404 \& C-4055/12P, Council v. Stichting Natuur en Milieu and Pesticide Action Network Europe (Aarhus Convention), 2015 EUR-Lex CELEX LEXIS 62012CJ0404 (13 January 2015) (holding that an NGO has no standing to invoke the Aarhus Convention in a challenge to the postponement of clean air requirements). 
agencies. Insofar as these lead to a negative impact on members of the consortium, or third parties, there appears to be an increase in the options to challenge such measures under domestic constitutional and WTO rules, or bilateral and regional trade and investment agreements containing ISDS. These ISDS clauses are commonly included in recent US and EU trade and investment agreements, also those with Asian partners. To date, only a limited number of such cases that have been brought involve IP rights. The likelihood of success appears limited, but several key cases are still pending. In ISDS complaints over IP enforcement, tribunals seem hesitant to accept jurisdiction over these cases. In the plain packaging tobacco cases, the question will be the extent to which WTO Members have policy freedom in articulating exceptions to WTO obligations.

EU GI specifications are very targeted and individual in nature, so that any measure affecting them may be considered arbitrary or discriminatory much more easily as compared to general policy measures affecting the use, grant or scope of a trademark, design, copyright or patent right. Furthermore, many specifications are rooted in culture and custom rather than in science and utility, which raises the chances of a dispute over arbitrariness and discrimination in standards imposed when determining issues of culture and custom. Finally, measures affecting GI specifications are often attributable to a public authority or agency. This combination increases the likelihood of success of claims for protection of GIs as property and investments. If, for example, an EU company takes over (i.e., invests) a business located in Vietnam or Korea that is involved in the production of a GI product, and the Vietnamese or Korean authority redefines the geographical area in such a way that the EU company can no longer use that GI, this could give rise to an ISDS case. The same could be true for a US company making investments in Asian jurisdictions. This should be taken into consideration when drafting or changing GI product specifications. 